\title{
Pemberdayaan Eks Pekerja Seks Komersial dalam Kajian Filsafat Ilmu
}

\author{
Evi Yulia', Mugi Harsono \\ ${ }^{1}$ Universitas Islam Lamongan, Indonesia \\ ${ }^{2}$ Universitas Sebelas Maret Surakarta, Indonesia \\ Email corresponding author: nh90579@gmail.com/mugiharsono_fe@staf.uns.ac.id
}

\begin{abstract}
ABSTRAK
Tujuan dari pemberdayaan memberikan ketrampilan dan pengetahuan kepada eks PSK, selain ketrampilan yang utama adalah penyadaran diri untuk meninggalkan bisnis prostitusi dengan startegi Spiritual building training semua dikaji dalam aspek ontologi. Fenomena, sarana dan tatacara yang dilakukan sebagai upaya pemberdayaan eks PSK dalam aspek epistomologis adalah strategi yang digunakan untuk memberdayakan eks PSK. Berangkat dari fenomena kemiskinan dan tren kasus prostitusi yang semakin tinggi hingga sarana yang berhubungan dengan fasilitas yang diberikan oleh pemerintah dalam menangani eks PSK adalah pembinaan mental spriritual, pelatihan, ketrampilan dan seminar adalah program-program pemberdayaan bagi para eks PSK. Tata cara yang dilakukan seperti penyadaran diri melalui pendekatan lingual bagi eks PSK. Pengukuran dari pemberdayaan dikaji dalam aspek aksiologi. Aksiologi berhubungan dengan hakikat akan nilai dari sesuatu. Berbagai kegiatan yang sudah dilakukan seperti kegiatan PUDUMA, aras mezzo, spiritual building tranining adalah program-program pemberdayaan eks PSK. Kagiatan ini memiliki nilai yang positif karena cukup berhasil dalam merubah perilaku bisnis prostitusi ke bisnis yang lebih baik. Pemberdayaan harus terus dilakukan artinya kegiatan ini harus berkelanjutan dan bersifat jangka panjang sebagai upaya untuk menumpas pantologi social yang terjadi di masyarakat. Menuju kesejahteraan yang bermoral
\end{abstract}

Kata Kunci: Pemberdayaan, aspek ontology, aspek epistomologis, aspek aksiologis

\section{PENDAHULUAN}

Fenomena tantang prostitusi merupakan fenomena umum namun juga universal. Pekerjaaan ini sudah ada sejak jaman nenek moyang dan masih eksis sampai saat ini bahkan terus meningkat jumlahnya setiap hari. Fakta terbaru dari kasus prostitusi adalah kasus prostitusi online via aplikasi media social miChat yang juga melibatkan anak-anak dan remaja yang masih duduk dibangku sekolah. Tren kasus prostitusi, online dikalangan anak-anak dan remaja terus meningkat jumlahnya apalagi di masa pandemi covid 19. Peningkatan kasus prostitusi online merupakan fenomena nasional, apalagi penggunaaan media social yang semakin aktif dimasa pandemi covid 19 dan semakin sulitnya perekonomian dunia yang menyebabkan semakin maraknya bisnis prostitusi dan menyebabkan banyak remaja dan anak-anak memilih jalan pintas untuk dapat bertahan dimasa pandemic covid 19. Fenomena prostitusi memiliki dampak yang sangat mengkhawatirkan dalam merusak moral bangsa

Masalah prostitusi ataupun PSK merupakan masalah yang sangat komplek karena berhubungan dengan tantanan nilai, moral agama, dan budaya masyarat. (Shodiq, dkk.,2014). Menurut Al rosyid, dkk (2017) Prostitusi merupakan perzinaan dengan menjual jasa untuk memuaskan kebutuhan seksual berupa menyewakan tubuh. prostitusi merupakan bentuk penyimpangan social, kejahatan terhadap masyarakat bahkan agama pun sangat melarang perbuatan ini. Dalam ilmu filsafat prostitusi atau PSK termasuk kedalam Pantologi social. 
Masalah prostitusi merupakan masalah yang dapat menghambat lajunya pembangunan karena dapat merugikan keslamatan, ketentraman jasmani, rohani, maupun social, karena itu kehadirannya mendapat banyak penolakan dari maasyarakat (Shodiq, dkk, 2014)

Menurut handayani (2016) kasus prostitusi tidak dapat sepenuhnya dibrantas dan tidak mungkin dapat hilang begitu saja meski sudah dilakukan upaya penutupan lokalisasi penyedia prostitusi untuk mempersempit ruang gerak mereka. Oleh karena itu dibutuhkan banyak strategi untuk menumpas kasus prostitusi. Salah satu strategi yang dapat dilakukan adalah strategi pemberdayaan. Menurut Bayu, Agung kresna dan Sonia Margareta M Strategi ini memiliki determinisme ekonomi dengan manifestasi (perut kenyang) hal ini penting agar upaya pemberdayaan terhadap PSK tidak hanya sosialisasi namun upaya untuk menggeser paradigm ekonomistik yang mereka anut. Upaya pemberdayaan merupakan upaya yang bertujuan untuk mengurangi ketimpangan dan meningkatkan kesejahteraan (Sumodiningrat, 1999)

Pemberdayaan merupakan proses penggalian potensi diri dari masyarakat yang belum terekpos atau belum diketahui oleh masyarakat sendiri terhadap potensi yang dimiliki, dengan pemberdayaan dapat menggali potensi diri yang ada pada masyarakat sehingga dapat mengembangkan kemampuan masyarakat dalam berkarya dan menghasilkan sesuatu yang lebih baik, postif dan tentunya berguna untuk banyak orang. Pemberdayaan merupakan upaya untuk membangun eksistensi seseorang dalam kehidupannya dengan memberi dorongan agar memiliki kemampuan atau keberdayaan (Wajdi, M. Barid N, 2016)

Dalam artikel ini pemberdayaan akan dikaji dalam filsafat ilmu. Filsafat ilmu merupakan penerusan dalam pengembangan filsafat pengetahuan, sebab pengetahuan ilmiah tidak lain adalah "a higher level" dalam perangkat pengetahuan manusia dalam arti umum sebagaimana yang diterapkan dalam kehidupan sehari-hari (Harsono, 2004). Pemberdayaan terhadap Pekerja Seks komersial adalah buah pemikiran yang diungkapkan oleh Pieere Bourdieou. Pemikiran Bourdieou menekankan pada dimensi sosiologis dan antropologis yang menjembatani pertarungan antara objektivitas dan subjektivitas (Ritzer, 2004). Subyek dari filsafat ilmu terdiri dari tiga pilar yaitu ontologism, epistomologis dan aksiologis. Ontologi mengkaji tentang hakikat kebenaran dan kenyataan yang inheren dengan pengetahuan ilmiah. Menurut Suriasumantri (1983), epistemologi disebut juga dengan teori pengetahuan, yang membahas secara mendalam segenap proses yang terlibat dalam usaha untuk memperoleh pengetahuan. Sedangkan aksiologi meliputi nilai-nilai yang bersifat normatif dalam pemberian makna terhadap kebenaran atau kenyataan sebagaimana dijumpai dalam kehidupan kita yang menjelajahi berbagai kawasan, seperti kawasan sosial, kawasan simbolik atau pun fisik material. (Harsono, 2004).

\section{Pemberdayaan Mantan PSK Dalam Aspek Ontologis}

Aspek ontologis yang dikaji pada artikel ini meliputi dua hal, yaitu apa hakikat pemberdayaan (empowerment) mantan pekerja seks komersial dan alasan apa yang membenarkan pemberdayaan (empowerment) mantan pekerja seks komersial menjadi subjek bahasan pada artikel ini. Pertanyaan apa hakikat dari pemberdayaan mantan pekerja seks komersial menunjuk pada definisi pemberdayaan (empowerment), sedangkan alasan apa yang membenarkan pemberdayaan (empowerment) menjadi subjek bahasan menunjuk pada unsur historis terbentuknya pemberdayaan sebagai upaya dalam membrantas kasus prostitusi.

Secara konseptual pemberdayaan atau pemberkuasaan (empowerment) berasal dari kata power yang artinya kekuatan, atau keberdayaan atau kekuasaan. pemberdayaan itu sendiri dikatakan (empowerment) adalah suatu cara dengan mana seseorang, rakyat, organisasi dan komunitas diarahkan agar mampu menguasai (berkuasa atas) kehidupannya (Suharto, 2003). Menurut Elizabet (2007) Pemberdayaan (empowerment) pada wanita merupakan upaya yang dilakukan untuk menunjukan penguatan terhadap segala yang berada dalam ketidakberdayaan 
sehingga pemberdayaan diharapkan mampu menolong dirinya sendiri dalam mengembangkan semangat kepercayaan yang telah ada. Ada banyak upaya pemberdayaan (empowerment) yang terus dilakukan untuk membrantas kasus protitusi hanya saja selama sangat sedikit sekali yang berhasil malah muncul kasus-kasus bru terkait prostitusi.

Hakikat dari pemberdayaan (empowerment) dipandang dari aspek ontologis adalah pemberian kekuatan kepada masyarakat yang dipandang lemah dari banyak sisi, baik dari sisi ekonomi, sisi ekologi, sisi pengetahuan, sisi social, sisi moral, sisi pendidikan, sisi agama dan sisi yang lain. Sehingga tidak mudah untuk memberdayakan seorang mantan pekerja seks komersial, butuh waktu, proses dan pendekatan yang tidak hanya satu atau dua kali dalam melakukan pemberdayaan untuk eks PSK. Dalam aspek ontologis prostitusi masuk dalam pantologi social yang dibahas lebih dalam terkait filsafat moral atau berhubungan dengan etika. Menurut frans magnis suseno mengapa etika perlu terutama dizaman milenial ini (Frans magni suseno, 1987) (a) Kita hidup dijaman dimana masyarakat semakin berfikir pluralistic sehingga butuh refleksi etika (b) Kita hidup di jaman transformasi masyarakat yang tanpa tanding. Modernisasi telah merubah cara berfikir masyarakat amat radikal (c) Proses perubahan telah banyak menawarkan ideology sebagai terapi penyelamat (d) Etika diperlukan oleh kaum agama yang disatu pihak menemukan dasar kemantapan mereka dalam iman kepercayaan mereka, dilain pihak mau berpartisipasi tanpa ragu-ragu dan tidak menutup diri dalam semua dimensi kehidupan masyarakat yang sudah berubah saati ini

Bagi whitehead dalam pandangannya mengenai etika (moralitas) bertumpu pada 2 kata kunci penting yaitu " process" dan "importance ". Moralitas sebagai process, berkaitan denga proses hidup seseorang, bagaimana memposisikan moralitas dalam dinamika kehidupan. Sehingga pemberdayaan (empowerment) sebagai upaya yang dilakukan untuk memberikan potensi baru kepada mantan PSK membutuhkan process yang cukup rumit karena berhubungan dengan moralitas kehidupannya di masyarakat. pemberdayaan (empowerment) terhadap eks PSK dari process awal yang merupakan pantologi social dipandang sebagai penyakit masyarakat beralih ke manusia yang memiliki moral baik tentunya tidak mudah. Banyak tahapan dari process pemberdayaan yang akan dilalui oleh eks PSK.

Kata kunci yang kedua "importance" merupakan bobot pengalaman hidup dari seseorang. Harus diupayakan maksimal Karena merupakan tujuan hidup bermoral. Pemberdayaan dilakukan untuk membuat kehidupan eks PSK kedepannya lebih baik tentunya beretika dan berakhlak sehingga mampu diterima oleh masyarakat dengan baik. Namun karena eks PSK memiliki pengalaman yang kurang baik sebelumnya, sehingga hal ini pun tidak mudah bagi eks PSK untuk mudah bersosialisasi dengan semua lapisan masyarakat. Dengan pemberdayaan (empowerment) tentunya diharapkan eks PSK memiliki kekuatan untuk bangkit, memiliki bekal dan dapat menggali potensi yang ada dalam dirinya, sehingga mereka bisa menghasilkan karya yang berguna untuk masyarakat.

\section{Pemberdayaan Mantan PSK Dalam Aspek Epistomologis}

Epistomologis memiliki peranan penting dalam ilmu filsafat. Beberapa bahasan dalam aspek epistemologis, antara lain meliputi sumber terjadinya fenomena pemberdayaan eks PSK, sarana yang digunakan untuk mendeteksi eksistensi Pemberdayaan (empowerment), serta tatacara untuk mengukur pemberdayaan (empowerment). Sumber fenomena Pemberdayaan (empowerment), akan mengarah pada beberapa peristiwa yang terjadi yang menyebabkan timbulnya pemberdayaan di masyarakat terutama eks PSK. sarana yang digunakan akan mengarah pada beberapa indikator yang dipakai untuk mendeteksi tingkat Pemberdayaan (empowerment), sedangkan tatacara untuk mengukur akan mengarah pada instrumen yang dipakai untuk pengukuran pemberdayaan eks PSK. Aspek epistomologis mengarah kepada metode yang digunakan untuk memberdayakan eks PSK. 
Fenomena pemberdayaan (empowerment) terjadi sebagai upaya dari pemerintah untuk eks PSK. Tingkat angka kemiskinan yang tinggi yang ada di Indonesia menyebabkan banyak sekali penyimpangan yang terjadi. Pantologi social yang terjadi dimasyarakatpun semakin meningkat saat dunia dilanda krisis perekonomian karena adanya dampak covid 19. Perekonomian di seluruh dunia pun melemah terutama di Indonesia, banyak PHK karyawan yang dilakukan oleh perusahaan karena menurunnya angka produktifitas, adanya pembatasan yang dilakukan oleh pemerintah untuk mencegah penyebaran covid 19. Kebutuhan yang terus meningkatpun membuat para wanita beralih profesi ke bisnis prostitusi untuk bisa bertahan di tengah rumitnya persaingan di tengah rumitnya prekonomian. Ada yang sekedar terjun ke bisnis prostitusi karena tuntutan gaya hidup yang tinggi seperti prostitusi di kalangan para artis. Ada yang terjun karena tuntutan kebutuhan sehari-hari. Kasus prostitusi pada anak-anak dan kalangan remaja sekolah pun menjadi perhatian lebih dari pemerintah untuk bisa membrantas prostitusi. Pemberdayaan sangat perlu dilakukan setidaknya untuk mengurangi tingginya angka prostitusi di Indonesia. Berkembangnya kasus prostitusi pastinya akan berpengaruh terhadap kesehatan mental masyarakat terutama masalah social dan kepribadian. Berangkat dari sinilah penanganan perlu dilakukan

Sarana yang digunakan untuk pemberdayaan untuk eks PSK adalah tempat rehabilitas social. Ditempat ini tentunya eks PSK akan mendapat pembinaan khusus terutama terhadap mental dan kepribadian mereka. Selain itu metode atau stimulus yang dapat diberikan oleh pemerintah melalui pemberdayaan untuk eks PSK adalah menurut (Shodiq, 2014) (a) Program pendampingan terhadap eks PSK (b) Pembinaan mental keagamaan untuk eks PSK seperti ESQ (emotional and spiritual quotient) mendatangkan penceramah atau pendakwah untuk kegiatan mental keagamaan (c) Mendatangkan institusi jasa psikolog terutama psikolog islami (d) Mengadakan tahsin al-qur'an (e) Spiritual building training (SBT) (f) Pelatihan kewirausahaan

Tahap pemberdayaan seperti yang diungkap Mintarti dalam Al Rosyid (2017) yaitu (a) Penyadaran (b) Pengorganisasian (c) Kaderisasi (d) Dukungan tekhnis (e) Pengolahan system. Pemberdayaan dilakukan melalui pemanfaatan sampah organic dan non organic pada eks PSK sehingga mantan PSK memiliki usaha sendiri dan memiliki penghasilan sendiri. Badan pemberdayaan dan pemerintah desa turut terlibat dalam kegiatan ini dengan memberikan pembinaan khusus terhadp eks PSK. Pemberdayaan harus bersifat berkelanjutan. Strategi yang dilakukan untuk mencapai hasil adalah startegi aras mezzo (Al Rosyid (2017)). Pemberdayaan dengan menggunakan kelompok sebagai media intervensi. Pendidikan, pelatihan, dinamika kelompok, seminar, dan memberdayaan diri sendiri dan masyarakat untuk meningkatkan kreatifitas dan perekonomia.

Langkah strategis dalam memberdayakan eks PSK menurut Bayu, Agung kresna dan Sonia Margareta M adalah (a) Penyadaran dengan pendekatan lingual. Masalah komplesitas faktor seperti faktor sosiologi, ketidakadilan social, faktor psikologi malas bekerja, gaya hidup yang tinggi (Ismail saleh M. Maiwan dan Raharjo (2013) yang membuat mereka akhirnya terjun kedunia prostitusi. Butuh penyadaran dan pendekatan yang intensif terhadap eks PSK. Sarana yang dapat diberikan adalah program-kepemimpinan dan pelatihan ketrampilan untuk membantu PSK perlahan bergeser profesi. Program-program ini harus didukung baik oleh PSK dan berpastisipasi didalamnya. Karena partisipasi merupakan pelicin pembangunan dan pemberdayaan. (b) Program pengenalan ketrampilan PUDUMA. Model ini bertujuan untuk mengembangkan kreatifitas dari PSK dengan memproduksi makanan dan aneka kerajinan yang ada secara kolektif.

Menurut Hamid, abdul ada 2 cara untuk memberdayakan ekonomi perempuan melalui usaha mikro yaitu bisnis konveksi. Pertama bimbingan ketrampilan usaha konveksi mulai dari tahap desaign sampai finishing. Kedua masing-masing personel dibimbing secara bertahap, 
disetiap tahap personel dibimbing agar memiliki ketrampilan khusus. Selain konveksi atau ketrampilan menjahit bisa dibekali dengan ketrampilan sablon melalui lembaga kursus atau lembaga pelatihan.

Menurut Mawarti, Sri dan Ismi Dwi A (2012) berdasarkan model PCIM , pemberdayaan perlu dilakukan antara lain (a) Perlu dukungan dari stakeholder baik pemerintah, swasta, LSM maupun perguruan tinggi (b) Adanya achievement motivation training terhadap perempuan (c) Adanya jejaring antar sesame perempuan pengusaha local (d) Pembentukan kelompok usaha bersama (e) Penumbuhan kreativitas melalui capacity building latihan ketrampilan (f) Intervensi terhadap perempuan pelaku usaha dengan memperhitungkan potensi pasar $(\mathrm{g})$ System bapak angkat perlu diperluas dengan melibatkan banyak pengusahawan (h) Memperkuat rasa percaya diri, kreativitas, inovasi tangguh terhadap situasi fluktuasi (i) Perbaikan diversifikasi produk, peningkatan kualitas produk. Adapun tata cara untuk mengukur keberhasilan pemberdayaan adalah menggunakan instrumen dengan skala pengukuran menggunakan skala likert.

\section{Pemberdayaan Eks PSK Dalam Aspek Aksiologis}

Aksiologi adalah salah satu cabang studi ilmu filsafat yang mempertimbangkan hakikat nilai dan benda-benda apa saja yang memiliki nilai. Aspek aksiologis dari filsafat mengkaji tentang hal-hal yang berkaitan dengan nilai dan moral dalam kehidupan manusia. Aksiologi lebih dari sekedar menyatakan apa yang berharga atau tidak berharga, mereka yang belajar di bidang ini mencoba mengemukakan alasan mengapa sesuatu memiliki nilai atau tidak. Dalam penulisan artikel ini membhasa tentang pemberdayaan eks PSK tentu saja ada nilai yang terkandung didalamnya. Upaya pemberdayaan untuk membrantas kasus prostitusi atau pantologi social yang terjadi dimasyarakat tentunya ada nilai besar dan berharga dari pemberdayaan eks PSK. Dalam aksiologi memunculkan 2 cabang ilmu filsafat yakni etika dan estetika. Etika mengajarkan manusia untuk bisa membedakan mana perbuatan baik dan salah. Sedangkan estetika menguji nilai-nilai subjektif dan sensori-emosional atau berhubungan dengan sentiment rasa

Ada Asumsi dasar manusia bahwa hanya perilaku yang sesuai dengan nilai-nilai etis (moral) yang dapat diterima oleh masyarakat. Etika merupakan ilmu yang menyelidiki tentang tingkah laku moral (Supriyono, 2009). Program pemberdayaan (empowerment) memiliki nilai yang baik dan berharga di mata masyarakat. Hal ini dapat diukur dari beberapa hasil penelitian yang dilakukan oleh beberapa peneliti sebelumnya. Penelitian yang dilakukan oleh Muh. Fajar Shodiq dkk di tahun 2014 memperoleh hasil yang cukup memuaskan dalam upaya pemberdayaan para mantan pekerja seks komersial yang dilakukan di balai rehabilitasi wanita di Surakarta. Upaya pemberdayaan yang dilakukan adalah pembinaan mental spriritual bagi para eks pekerja seks komersial dengan 5 program utama yakni bimbingan baca Al- Qur'an, Spiritual Building Training (SBT), pendampingan psikologi, pengajian dan pelatihan kewirausahaan. Kegiatan ini mendapat sambutan yang sangat baik dari masyarakat dan penerima manfaat yaitu eks PSK. Tanggapan positif dari para peserta dan masyarakat membuktikan jika program ini cukup sukses dan sangat membantu untuk membrantas penyakit masyarakat yang kian bertambah. Sehingga ada nilai lebih dari kegiatan pemberdayaan untuk eks PSK

Untuk mengkaji lebih dalam terkait pemberdayaan eks PSK dalam aspek aksiologi. Penelitian selanjutnya dilakukan oleh Muh. Harun Al Rosid, dkk di tahun 2017 upaya pemberdayaan dilakukan untuk Eks mucikari melalui pemanfaatan sampah organik dan non organik . pemberdayaan dilakukan dengan pelatihan pemanfaatan sampah. Kegiatan ini mendapat respon yang sangat baik dari masyarakat karena lokasi merupakan mayoritas pengepul sampah sehingga sangat cocok untuk meningkatkan penghasilan mantan mucikari. 
Dalam aksiologi kegiatan ini memiliki etika yang baik karena pemberdayaan memiliki nilai bagi masyarakat dan berguna bagi kelangsungan hidup para eks PSK.

Penelitian yang dilakukan oleh Agung kresna bayu dan Sonia margareta $M$ pemberdayaan kegiatan eks PSK dengan kegiatan PUDUMA melalui pemanfaatan digitalisasi dan pengembangan ekonomi kreatif online. PUDUMA merupakan realisasi program pemberdayaan kepada eks PSK, kegiatan ini bertujuan untuk melakukan pembaharuan terhadap integritas dan mentalitas ekonomi dan pembaharuan pada habitus para eks PSK. Kegiatan ini mendapat dukungan yang sangat baik dari masyarakat. Kegiatan ini merubah habitus para eks PSK yang merupakan penyakit masyarakat yang meresahkan karena dapat menghambat laju pembangunan, merugikan keslamatan, menggangu ketrentaman jasmani dan rohani. Adanya program pemberdayaan sangat membantu masyarakat dan pemerintah dalam membrantas pantologi social yang terjadi di masyarakat.

Dari penjelasan diatas dapat diukur dari hasil penelitian terdahulu yang dilakukan oleh beberapa peneliti, kegiatan pemberdayaan memiliki nilai etika dan estetika. Kegiatan ini mengarah pada filsafat moral, merubah moral eks PSK, merubah perilaku yang buruk ke perilaku yang lebih baik. Merubah cara berfikir dengan mengikuti pembinaan dan pelatihan yang bertujuan untuk meningkatkan pengetahuan berwirausaha. Kegitan pemberdayaan eks PSK memiliki nilai yang berharga dimata masyarakat dalam menumpas pantologi social yang terjadi di lingkungan mayakarat yang terus meningkat jumlahnya setiap hari. Kegiatan pemberdayaan harus dilakukan secara berkelanjutan agar eks PSK tidak terpengaruh untuk kembali kedunia yang menjerumuskan mereka ke limbah kenistaan.

Kerangka 1. model konseptual

\begin{tabular}{|l|l|l|}
\hline Mantan PSK & \multicolumn{1}{|l|}{$\begin{array}{l}\text { PEMBERDAYAAN } \\
\text { Penyadaran diri } \\
\text { Spiritual building training } \\
\text { Pelatihan kewirausahan } \\
\text { Seminar } \\
\text { Strategi puduma } \\
\text { Capacity building }\end{array}$} \\
\cline { 2 - 2 }
\end{tabular}

\section{KESIMPULAN}

Pemberdayaan eks PSK di kaji dalam 3 pilar filsafat ilmu yaitu aspek ontologis, aspek epistomologis dan aksiologis. Hakikat dari pemberdayaan (empowerment) dipandang dari aspek ontologis adalah pemberian kekuatan kepada masyarakat yang dipandang lemah dari banyak sisi yang kompleks. Dengan pemberdayaan diharapkan eks PSK memiliki ketrampilan dan pengetahuan untuk mengelolah potensi yang ada pada diri mereka sehingga ada perubahan perilaku dari bisnis yang mereka jalankan. Fenomena, sarana dan tatacara yang dilakukan sebagai upaya pemberdayaan eks PSK dalam aspek epistomologis adalah strategi yang digunakan untuk memberdayakan eks PSK. Berangkat dari fenomena kemiskinan dan tren 
kasus prostitusi yang semakin tinggi hingga sarana yang berhubungan dengan fasilitas yang diberikan oleh pemerintah dalam menangani eks PSK adalah pembinaan mental spriritual, pelatihan, ketrampilan dan seminar adalah program-program pemberdayaan bagi para eks PSK.

Tata cara yang dilakukan seperti penyadaran diri melalui pendekatan lingual bagi eks PSK. Pengukuran dari pemberdayaan dikaji dalam aspek aksiologi. Aksiologi berhubungan dengan hakikat akan nilai dari sesuatu. Berbagai kegiatan yang sudah dilakukan seperti kegiatan PUDUMA, aras mezzo, spiritual building tranining adalah program-program pemberdayaan eks PSK. Kagiatan ini memiliki nilai yang positif karena cukup berhasil dalam merubah perilaku bisnis prostitusi ke bisnis yang lebih baik. Pemberdayaan harus terus dilakukan artinya kegiatan ini harus berkelanjutan dan bersifat jangka panjang sebagai upaya untuk menumpas pantologi social yang terjadi di masyarakat. Menuju Indonesia lebih baik.

\section{DAFTAR PUSTAKA}

Al Rosyid, Muh Harun, et al. 2017. Pemberdayaan mantan mucikari emallui pemanfaatan sampah organic dan non organic pada eks lokalisasi padang pasir rogojampi Banyuwangi. Jurnal pengabdian masyarakat engagement vol.01 no.01, 28-47

Bayu agung Kresna, Sonia Margaretha M. pemberdayaan pekerja seks komersial pasar kembang dengan gerakan puduma melalui pemanfaatan digitalisasi dan pengembangan ekonomi kreatif online. academi.edu

Bertens, kees, etika. 1999. Gramedia, Jakarta

Edi Suharto. 2003. Pembangunan kebijakan dan kesejahteraan social. Bandung: Mizan

Hamid, abdul.2015. pemberdayaan ekonomi perempuan melalui usaha mikro konveksi. Jurnal studi gender dan anak.

Harsono, Mugi. 2004. Organizational Citizenship behavior dalam kajian filsafat ilmu. Jurnal ekonomi dan kewirausahaan volume 4 nomor 1, 1-7

Jujun S. Suriasumantri, Ilmu Dalam Perspektif (Jakarta: Yayasan Obor Indonesia, 1983), h. 9.

Marwanti \& Nurhaeni, 2011. Model pemberdayaan perempuan miskin melalui pengembangan kewirausahaan keluarga men uju ekonomi kreatif di kabupaten karanganyar . P3G LPPM UNS (laporan penelitian)

Purwosaputro, Supriyono. 2009. Sudut Pandang Etika- Moral filsafat Ornasisme (filsafat proses). Majalah ilmiah lontar. Agustus Volume 23 nomer 3

Ritzher, George \& Douglas J. Goodman, 2004. Teori sosiologi Modern. Jakarta : Prenada Media.

Shodiq, Muh. Fajar,et al.2014. pengembangan social kemsyarakatan pembinaan mental spiritual bagi para mantan pekerja seks komersial (PSK) di Surakarta. Seminar nasional dan call for papers UNIBA.

Suharto, edi , membangun masyarakat memberdayakan rakyat, bandung : PT. Rafika Aditama. 2005

Sumodiningrat, Gunawan. 1999. Pemberdayaan Masyarakat dan jarring pengaman social. Jakarta : Gramedia Pustaka Utama

Suseno, Franz magnis, etika dasar- masalah-masalah pokok filsafat moral. 1987, kanisius, Yogyakarta

Syairozi, M. I., \& Fattah, A. (2018). "Youth Creative Enterpreneur Empowerment (YOUTIVEE)": Solusi Bagi Kaum Muda untuk Berkonstribusi Pada PEREKONOMIAN dan Mengurangi Pengangguran. Jesya (Jurnal Ekonomi dan Ekonomi Syariah), 1(2), 43 55 .

Wajdi, M Barid Nizarudin “ harmonisasi nilai pendidikan islam dengan kearifan budaya local “ jurnal studi islam : pancawahana 11, no 1 (2016) : 51-78 
Wijaya, K., \& Syairozi, M. I. (2020). Analisis perpindahan tenaga kerja informal Kabupaten Pasuruan. Jurnal Paradigma Ekonomika, 15(2), 173-182.

Whitehead, Alfred North, Adventures Of Ideas. 1967, The free press. New York

Whitehead, Alfred North, modes of thougth, 1967, The free press. New York

Whitehead, Alfred North, process and reality - Corrected edition, edited by david ray griffin and Donald W Sherburne, 1979, The free press. New York

Zaki, Muhammad. 2020. Hijarahnya pelaku prostitusi ; studi perubahan perilaku mantan mucikari di eks lokalisasi bangunsari, Surabaya. Jurnal dakwah dan social Vol 3 nomor 01. 35-54

Zakiyah , pemberdayaan perempuan oleh lajanah wanita, jurnal pengkajian masalah social keagamaan, XVII,01(januari-juni), 2010 hlm, 44 